Inna Tiutiunyk,

D.Sc., Associate Professor, Sumy State University, Ukraine

ID ORCID ID: 0000-0001-5883-2940

email: i.karpenko@finance.sumdu.edu.ua

Andrii Zolkover,

Ph.D., Associate Professor, Kyiv National University of Technologies and Design, Ukraine

iD ORCID ID: 0000-0002-8176-1850

email: zaaaaa@ukr.net

Vladyslav Maslov,

Banking University, Ukraine

ID ORCID ID: 0000-0002-2241-6424

email: anschluss@ukr.net;

Nataliia Vynnychenko,

D.Sc., Associate Professor, Sumy State University, Ukraine

(iD) ORCID ID: 0000-0002-6730-4629

email: n.vynnychenko@uabs.sumdu.edu.ua

Mehriban Samedova,

Ph.D., Associate Professor, Azerbaijan State University of Economics, Azerbaijan

e-mail: mehriban_samadova@unec.edu.az

iD ORCID ID: 0000-0002-7022-0936

Yevgenia Beshley,

Private entrepreneur, Canada

Olena Kovalenko,

Private entrepreneur, Ireland

Correspondence author: i.karpenko@finance.sumdu.edu.ua

\title{
INDICES OF INNOVATION ACTIVITY AS COMPONENTS OF MACROECONOMIC STABILITY ASSESSMENT: HOW DOES THE SHADOWING OF INVESTMENT FLOWS AFFECT?
}

Abstract. The article focuses on the study of causal links between the level of innovation development and the shadow economy on the example of 10 European countries. Based on the analysis of existing approaches to determining the level of innovation activity in the country, a linear model for evaluating the Complex Innovative Activity Index is proposed. The main hypothesis of the paper was the assumption that the increase in the level of the shadow economy is accompanied by a decrease in the country's innovative development, deteriorating access to financial resources, and so on. The purpose of the paper is to analyze the correlation between the level of the shadow economy and the indicators of innovative development of the country as components of its macroeconomic stability using Panel data analysis from 2007 to 2018. Unlike previous studies, this research considered that level of innovative development increasingly depends on the level of the shadow economy. The results confirm the relationship between factor and result indicators for all analyzed countries. To test the hypotheses about the negative impact of the shadow economy on the level of innovative activity of the country was presented the linear model with Complex Innovative Activity Index as an integral indicator of 8 international indexes (Global Competitiveness Index, Digital Readiness Score, Digital Economy and Society Index, Knowledge Economic Index, The European Innovation Scoreboard,

Cite as: Tiutiunyk, I., Zolkover, A., Maslov, V., Vynnychenko, N., Samedova, M., Beshley, Y., \& Kovalenko, O. (2020). Indices of innovation activity as components of macroeconomic stability assessment: how does the shadowing of investment flows affect?. Marketing and Management of Innovations, 4, 26-40. http://doi.org/10.21272/mmi.2020.4-02 
l., Tiutiunyk, A., Zolkover, V., Maslov, N., Vynnychenko, M., Samedova, Y., Beshley, O. Kovalenko. Indices of innovation activity as components of macroeconomic stability assessment: how does the shadowing of investment flows affect?

Bloomberg Innovation Index, The International Innovation Index, Global Innovation Index) characterizing the level of innovative development of the country. In the second stage: testing of the data series for stationarity by the DickeyFuller and Philips Perron test Statistics, calculation of the optimal lag length from the maximum possible selected by the Akaike criteria, the Hannan-Quinn Information Criterion and the Schwartz Information Criterion, verification of cointegration of data series using Johansen test are performed. Empirical calculations have proved the high impact of the shadow economy on the innovative development of the country. All indices are statistically significant at the level of $1 \%$ and $5 \%$ and $10 \%$ respectively. It is substantiated that the state should take into account interdependencies as a basis for the development and implementation of measures aimed at increasing the innovative activity of economic entities, increasing the innovation potential of the country, and so on.

Keywords: innovative activity, investment flows, macroeconomic stability, shadow economy, indices.

Introduction. Stability is the basis of any successful efforts for the development of the private sector and economic growth of the country, serves as a guarantee of stability of business operations, growth of investment in the official sector of the economy. One of the most generalizing indicators that determine the level of economic development of the country is macroeconomic stability, which is a complex indicator that reflects the efficiency of certain sectors of the economy.

In the context of the exacerbation of the global economic crisis, the shortage of resources in most countries, one of the most studied modern phenomena of the national economy is shadowing. The shadow economy is a complex phenomenon, which is characterized by multiple influences on individual components of the economy, a set of negative manifestations and undesirable consequences for both the country and society.

One of the most threatening consequences of the shadowing of the economy is a significant deterioration in its economic development, in particular: reduction of budget revenues, increasing its deficit, significant reduction of tax revenues, reduction of investment and innovation potential of the country, and so on. To date, the share of the shadow economy fluctuates within $10-40 \%$ of GDP. In Advance Economies the level of the shadow economy is 10-20\% of GDP, in Emerging economies - 3035 percent of GDP, in CIS countries these values exceed 40\% (Schneider, 2015; IFFR, 2018). According to the United Nations Office on Drugs and Crime (2018), 2 to $5 \%$ of the world GDP is formed in the shadow economy.

The propensity of economic agents to participate in shadow operations is often studied by scientists as the greatest threat to the country's economic security and stable functioning. Governments and international organizations are constantly developing measures to reduce the level of the shadow economy, the whole set of which can be divided into stimulating and restrictive. If restrictive measures provide for coercive influence on economic entities, stimulating measures - reduction of shadow operations due to the growth of economic and social development of the country.

Literature Review. The essence of macroeconomic stability, its indicators, their relationship with the level of the shadow economy investigated by scientists from around the world.

Given the multicomponent indicator of the stability of the national economy, today there are a significant number of approaches to its evaluation.

For example, Kendiukhov and Tvaronaviciene (2011) proposed to assess the level of macroeconomic stability with the help of five indicators: GDP growth, unemployment, inflation, the state budget balance to GDP, the balance of current turnover to GDP. The author considered the integrated indicator in the form of a pentagon, the lines of which characterize the degree to which countries have achieved the set macroeconomic goals.

A. Subramanian and S. Satyanath (2004) defined the institutional environment as the main indicator of macroeconomic stability, the catalyst for the growth of economic shadowing. Scientists have identified effective institutions of power as a prerequisite for reducing the level of shadowing in the country. 
l., Tiutiunyk, A., Zolkover, V., Maslov, N., Vynnychenko, M., Samedova, Y., Beshley, O. Kovalenko. Indices of innovation activity as components of macroeconomic stability assessment: how does the shadowing of investment flows affect?

M. Varudakis-Veganzones (2001) to the basic indicators of macroeconomic stability, the variable value of which most leads to an unstable macroeconomic situation and imbalances in the economy, include: inflation and the share of government deficit in GDP. These indicators lead to various distortions in the economy and the existence of a parallel foreign exchange market.

C. Lovell (1995) used methods of mathematical programming to measure economic stability. They allow to determine the limit values of macroeconomic indicators and further evaluate the economic results through the analysis of their effectiveness. The author studied the level of their macroeconomic stability for the period from 1970 to 1988 on the example of 10 Asian countries and 17 OECD countries. According to the study, Lovell established a scalar indicator of macroeconomic stability, which takes into account the following indicators: GDP growth, employment, trade balance and price stability.

The analysis reveals a significant number of indicators of macroeconomic stability that are directly related to the level of shadowing of the economy, in particular: the share of government deficit in GDP, inflation, real interest rates, nominal rates, savings and investment in the country.

Thus, the generalization of the results of empirical research (Formankova et al., 2018; Zarutska et al., 2020; Bobenic et al., 2018; Bilan et al., 2019) showed that most often scientists study the impact of the shadow economy on the following components of macroeconomic stability:

1. The volume of gross public debt as an indicator of the state of the national economy and an inhibitor of its economically sustainable development.

2. The volume of real GDP as an indicator that reflects the performance of economic entities of the country.

3. Inflation rate - a characteristic of the purchasing power of the population.

4. Unemployment rate - an indicator that reflects the effectiveness of government social policy.

5. The number of tax revenues

6. The exchange rate of the national currency to the US dollar.

At the same time, in our opinion, the connection of the shadow economy with the indicators of innovative development of the country as one of the main components that determine the potential for growth of production capacities, development of scientific researches, etc. is the least studied.

Some aspects of this phenomenon are investigated by scientists from around the world (Bakari et al, 2018; Kapidani and Luci, 2019; Loukil, 2016; Sekhar and Gudimetla, 2013; Tiutiunyk et al, 2019; 2020). A large share of budget resources is used to stimulate innovative development in most countries. Despite many incentives in the field of innovation development, today the level of innovation activity in most countries remains low. One of the reasons for this situation is the presence of the shadow sector of the economy.

Given that significant amounts of financial resources, including innovation, are derived from the official sector of the economy, and stable economic development of the country is impossible without funding innovative measures, it would be appropriate to analyze the statistical significance between innovative activity and the level of the shadow economy.

Most previous studies focus mainly on a more general analysis of the relationship between indicators of macroeconomic stability of individual countries in the context of inflation, GDP, exchange rates, foreign investment and the level of the shadow economy. At the same time, a considerable amount of our work is devoted to the study of the shadow economy and its impact on the indicators of innovative activity of the European countries, developing an approach to assessing the level of innovation development.

Thus, researchers consider the growing level of innovative development of the country as a prerequisite for de-shadowing the economy. Thus, some researchers consider innovative technologies as a tool for increasing the transparency of financial transactions and withdrawing cash flows from the shadows. 
l., Tiutiunyk, A., Zolkover, V., Maslov, N., Vynnychenko, M., Samedova, Y., Beshley, O. Kovalenko. Indices of innovation activity as components of macroeconomic stability assessment: how does the shadowing of investment flows affect?

One group of scientists claimed the stimulating effect of innovative activity on the level of the shadow economy. Digitization of the economy, the growing share of Internet business is an additional mechanism for shadowing incomes, increasing the share of informal employment, illegal withdrawal of funds abroad, and so on. This problem becomes especially relevant in the context of the growing share of electronic financial transactions. In this context, digital operations are seen as an integral part of the shadow sector of the economy, a tool of cybercrimes, tax evasion, money laundering and more.

According to the second approach, innovative development, which is manifested in the digitalization of the economy, the emergence of electronic payments, financial innovations leads to a decrease in the level of the shadow economy and increased control over cash flow.

Levchenko et al. (2018) claimed that innovative financial technologies are the most important instrument for ensuring macroeconomic stability of the country and withdrawing funds from the shadows.

Muhammad et al. (2020) considers innovation as an integral part of economic sector development and an important determinant of the economic stability of the country. Mane researches confirm that innovation activity is a driver of economic stability and growth (Bara and Calvin, 2016; Beck et al., 2012; Błach, 2011; Bara et a.l, 2016; Kozubikova and Kotaskova, 2019).

According to Chou and Chin (2011), the demand for innovation can result from economic reforms, which can be beneficial for companies and have the potential for improving their business model. Effective stimulation of innovation is dependent not only on the form of regulation but also on the flexibility, understood as openness and transparency of economic policy.

The purpose of the paper is to empirically substantiate the causal links between the level of the shadow economy and the indicators of innovative development of the country as components of its macroeconomic stability.

Methodology and research methods. The research of causal links between the levels of the shadow economy and indicators of innovative development of the country will be carried out using the STATA software package for the sample from 10 European countries for 2007-2018. The limitation of the period is due to the lack of data for individual indices of innovative development in the databases of the World Bank, IMF, World Economic Forum, European Commission, Boston Consulting Group.

The nexus between macroeconomic stability and shadow economy has not been unleashed through empirical investigation before. Literature produced evidence proving the correlation between shadow economy and macroeconomic stability variables, such as GDP, tax revenues, interest rate, foreign direct investments, the share of profitable companies and so on.

Given the important role of innovative development of the country in ensuring its economic stability, it can be presumed that there is a relationship between the levels of innovative activity and the shadow economy in the country. Given the significant variety of indicators that characterize the level of innovative development of the country, the study of communication will be carried out using the Complex Innovative Activity Index, which combines 8 indicators characterizing the level of innovative technologies and financial development. The calculation of the index is based on a linear model in which the individual components are weighted by the weighting coefficients. The characteristics of the subindexes used for the calculation are presented in Table 1.

Table 1. Indexed Components of Complex Innovative Activity Index

\begin{tabular}{c|c|c}
\hline Index & Methodology & Source \\
\hline $\begin{array}{c}\text { Sub-index «Innovation } \\
\text { capability» of the Global } \\
\text { Competitiveness Index } \\
(\mathrm{GCl})\end{array}$ & $\begin{array}{c}\text { Includes five components: Entrepreneurial Culture, } \\
\text { Interaction And Diversity, Research And } \\
\text { Development, Commercialization, Administrative } \\
\text { Requirements }\end{array}$ & $\begin{array}{c}\text { World } \\
\text { Economic } \\
\text { Forum }\end{array}$ \\
\hline
\end{tabular}


I., Tiutiunyk, A., Zolkover, V., Maslov, N., Vynnychenko, M., Samedova, Y., Beshley, O. Kovalenko. Indices of innovation activity as components of macroeconomic stability assessment: how does the shadowing of investment flows affect?

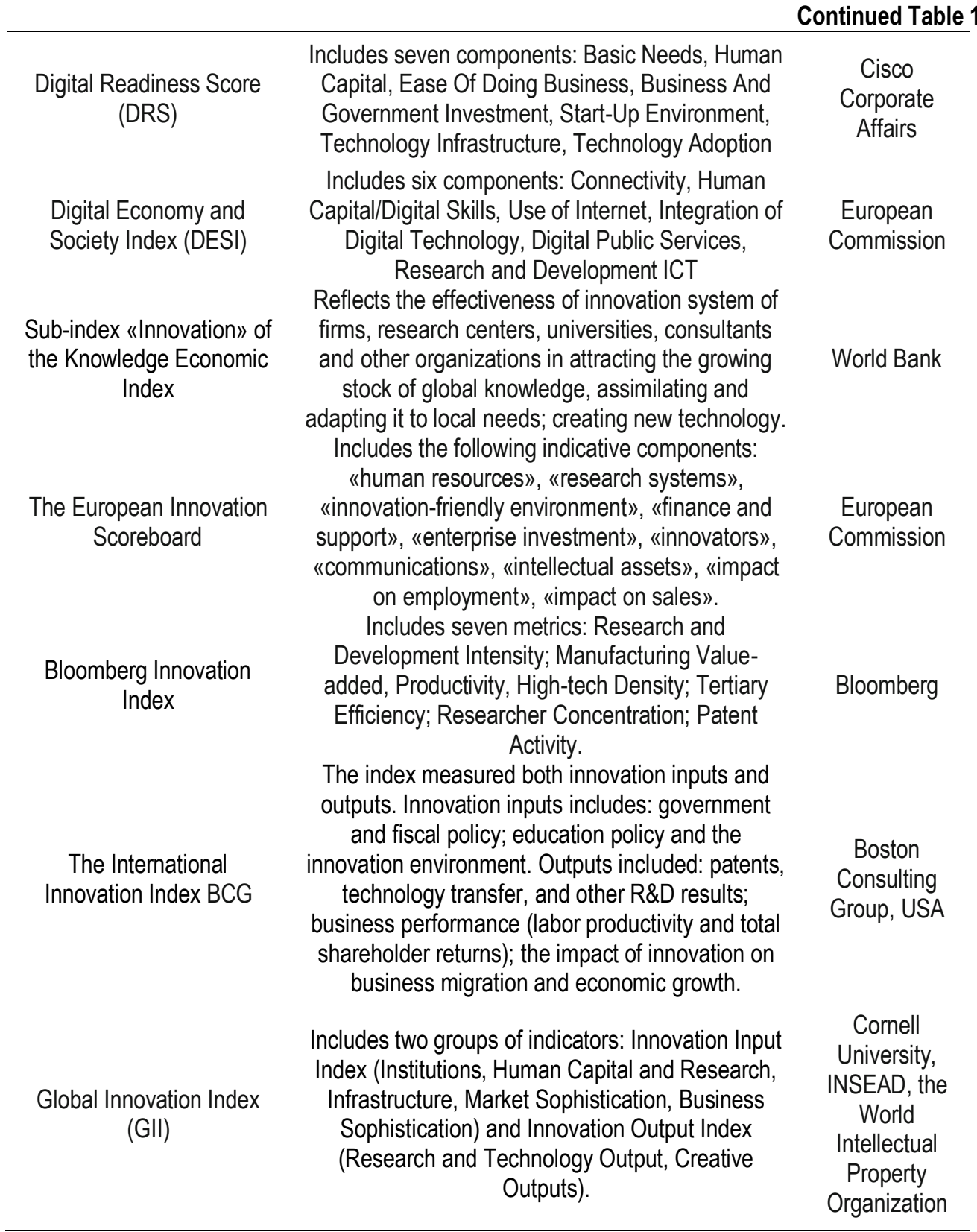

Source: developed by the authors on the basis of (World Bank ,2020; The Global Innovation Index, 2019; Bloomberg Innovation Index, 2020; Cisco Global Digital Readiness Index,2019; European Commission, 2020; Global Competitiveness Report, 2020). 
I., Tiutiunyk, A., Zolkover, V., Maslov, N., Vynnychenko, M., Samedova, Y., Beshley, O. Kovalenko. Indices of innovation activity as components of macroeconomic stability assessment: how does the shadowing of investment flows affect?

The evaluation of the Complex Innovative Activity Index will be carried out according to the following formula:

$$
C I A I=w_{G C I} \cdot G C I+w_{D R S} \cdot D R S+w_{D E S I} \cdot D E S I+w_{K E I} \cdot K E I+w_{E I S} \cdot E I S
$$

where, $\mathrm{w}_{\mathrm{i}}-\mathrm{a}$ weighting coefficient of indicator $\mathrm{i}$.

The rating of sub-indices of the Complex Innovative Activity Index will be performed using the Fishburne formula, which has the following form:

$$
W_{n}=\frac{2 \cdot(N-n+1)}{N \cdot(N+1)}
$$

where, $\mathrm{N}$ is the total number of sub-index; $\mathrm{n}$ - the rank of the sub-index.

The priority of sub-indices will be determined by Expert Assessment Methods.

The hypothesis on the impact of shadow investment flows on the country's innovative development indicators will be tested using economic and mathematical modeling tools.

In the first stage, the correlation analysis of the relationship between the defined indicators will be performed using the Multiple regressions method (OLS model), which has the following form:

$$
Y=\beta_{0}+\beta_{1} X_{1}+\beta_{2} X_{2}+\ldots+\beta_{k} X_{k}+\varepsilon
$$

where, the betas $\left(\beta_{k}\right)$ are the parameters that OLS estimates; epsilon $(\varepsilon)$ is the random error.

Scientists have developed a significant toolkit to study the causal links between the level of the shadow economy and indicators of macroeconomic stability in the country. The Dickey-Fuller and Philips Perron test will be used to test the hypothesis of stationarity of the studied data set. Data cointegration will be determined using the Johansen test. The optimal duration of the lag will be determined by the Akaike criteria, the Hannan-Quinn Information Criterion and the Schwartz Information Criterion.

At the last stage of the study to test the dependencies between the levels of the shadow economy and innovative component of macroeconomic stability index will use the approach proposed by Granger based on the construction of time series and regression equation to the following:

$$
y_{t}=\beta_{0}+\sum_{j=1}^{m} \beta_{j} y_{t-j}+\sum_{j=1}^{m} \beta_{j} x_{t-j}+e_{t}
$$

The application of this approach will allow checking the existence of a causal link between the shadow economy and the innovative development of the country in terms of the following hypotheses:

1. The presence of a one-way causal relationship between the analyzed indicators. The change in the level of the shadow economy causes a change in the level of innovation activity, but not vice versa.

2. The presence of a two-way relationship between factor and result indicators growth of the shadow economy causes a change in the level of innovation activity in the country and vice versa:

$$
\sum_{j=1}^{n} \tau_{j} \neq 0
$$


I., Tiutiunyk, A., Zolkover, V., Maslov, N., Vynnychenko, M., Samedova, Y., Beshley, O. Kovalenko. Indices of innovation activity as components of macroeconomic stability assessment: how does the shadowing of investment flows affect?

$\sum_{j=1}^{m} \rho_{j} \neq 0$

3. Lack of relationship between the analyzed indicators.

Results. Based on formula 2, the weights coefficient for sub-indices of Complex Innovative Activity Index were determined, the values of which are given in Table 2.

Table 2. Weighting coefficients for sub-indices of Complex Innovative Activity Index

\begin{tabular}{lcc}
\hline \multicolumn{1}{c}{ Sub-index } & The rank & Weighting coefficient \\
\hline Global Competitiveness Index & 8 & 0,027778 \\
Digital Readiness Score & 6.5 & 0,069444 \\
Digital Economy and Society Index & 6.5 & 0,069444 \\
Knowledge Economic Index & 5 & 0,111111 \\
The European innovation scoreboard & 4 & 0,138889 \\
Bloomberg Innovation Index & 3 & 0,166667 \\
The International Innovation Index BCG & 2 & 0,194444 \\
Global Innovation Index (GII) & 1 & 0,222222 \\
\hline
\end{tabular}

Source: developed by the authors.

Table 3. Complex Innovative Activity Index for European countries

\begin{tabular}{lcccccccccc}
\hline & BEL & CZE & DEU & DNK & ESP & FRA & GBR & HRV & EST & AUT \\
\hline $\mathbf{2 0 0 7}$ & 47.02 & 46.30 & 54.12 & 55.06 & 43.64 & 51.35 & 57.21 & 35.67 & 46.20 & 47.97 \\
$\mathbf{2 0 0 8}$ & 47.27 & 46.55 & 54.41 & 55.35 & 43.87 & 51.63 & 57.52 & 35.86 & 46.45 & 48.23 \\
$\mathbf{2 0 0 9}$ & 47.58 & 46.86 & 54.77 & 55.72 & 44.17 & 51.97 & 57.90 & 36.10 & 46.76 & 48.55 \\
$\mathbf{2 0 1 0}$ & 48.08 & 47.34 & 55.34 & 56.30 & 44.62 & 52.51 & 58.50 & 36.47 & 47.24 & 49.05 \\
$\mathbf{2 0 1 1}$ & 48.08 & 47.34 & 55.34 & 56.30 & 44.62 & 52.51 & 58.50 & 36.47 & 47.25 & 49.06 \\
$\mathbf{2 0 1 2}$ & 47.94 & 47.21 & 55.18 & 56.14 & 44.50 & 52.36 & 58.34 & 36.37 & 47.11 & 48.92 \\
$\mathbf{2 0 1 3}$ & 48.22 & 47.48 & 55.50 & 56.46 & 44.75 & 52.66 & 58.67 & 36.58 & 47.38 & 49.20 \\
$\mathbf{2 0 1 4}$ & 48.25 & 47.52 & 55.54 & 56.50 & 44.79 & 52.70 & 58.71 & 36.60 & 47.42 & 49.24 \\
$\mathbf{2 0 1 5}$ & 48.47 & 47.73 & 55.79 & 56.76 & 44.99 & 52.94 & 58.98 & 36.77 & 47.63 & 49.46 \\
$\mathbf{2 0 1 6}$ & 48.95 & 48.20 & 56.34 & 57.31 & 45.43 & 53.46 & 59.56 & 37.13 & 48.10 & 49.94 \\
$\mathbf{2 0 1 7}$ & 48.80 & 48.05 & 56.17 & 57.14 & 45.29 & 53.30 & 59.38 & 37.02 & 47.95 & 49.79 \\
$\mathbf{2 0 1 8}$ & 48.47 & 47.73 & 55.79 & 56.76 & 44.99 & 52.94 & 58.98 & 36.77 & 47.63 & 49.46
\end{tabular}

BEL - Belgium, CZE - Czech Republic, DEU - Germany, DNK - Denmark, ESP - Spain, FRA France, GBR - United Kingdom, HRV - Croatia, EST - Estonia, AUT - Austria,

Source: developed by the authors on the basis of World Economic Forum, Cisco Corporate Affairs, European Commission, World Bank, European Commission, Bloomberg, Boston Consulting Group, Cornell University, INSEAD, the World Intellectual Property Organization Data. 
I., Tiutiunyk, A., Zolkover, V., Maslov, N., Vynnychenko, M., Samedova, Y., Beshley, O. Kovalenko. Indices of innovation activity as components of macroeconomic stability assessment: how does the shadowing of investment flows affect?

The values of the Complex Innovative Activity Index allow us to conclude about the average level of innovative activity of the analyzed countries. During 2007-2018, its average value does not exceed 50.44 . Germany (55.36), Denmark (56.32) and United Kingdom (58.52) have the highest average level of innovation activity for the analyzed period. The lowest rates are typical for Croatia (36.48), Czech Republic (47.36) and Estonia (47.26).

One of the reasons for this situation, in our opinion, is the high level of the shadow economy of these countries, which significantly limits their innovation and investment potential.

The correlation analysis carried out using the Multiple regressions method indicates the causal links between the level of the shadow economy and the Complex Innovative Activity Index for 10 European countries. Most results are statistically significant at $0.05 \%$. Indicators of the Multiple regressions model are shown in Table 4.

Table 4. Indicators of the Multiple regressions model for Complex Innovative Activity Index and level of shadow economy for European countries

\begin{tabular}{ccc}
\hline Country & Indicator & Constanta \\
\hline BEL & $-1.306529^{* *}$ & $-1.165245^{* *}$ \\
& $(0.249661)$ & $(0.101118)$ \\
CZE & $-2.432964^{*}$ & $-2.315414^{*}$ \\
& $(0.557564)$ & $(0.125491)$ \\
DEU & $-2.473821^{* *}$ & $-2.021179^{* *}$ \\
& $(0.588984)$ & $(0.171629)$ \\
DNK & $-3.584366^{* *}$ & $-2.877324^{* *}$ \\
ESP & $(3.836912)$ & $(0.726841)$ \\
& $-1.306529^{*}$ & $-1.165245^{*}$ \\
FRA & $(0.249661)$ & $(0.101118)$ \\
& $-1.393482^{* *}$ & $-1.242795^{* *}$ \\
GBR & $(0.266277)$ & $(0.107848)$ \\
& $-2.594883^{* *}$ & $-2.46951^{* *}$ \\
HRV & $(0.594671)$ & $(0.133842)$ \\
& $-2.638459^{* *}$ & $-2.155694^{* *}$ \\
EST & $(0.628183)$ & $(0.183052)$ \\
& $-3.822913^{* *}$ & $-3.068816^{* *}$ \\
AUT & $(4.092268)$ & $(0.775214)$ \\
& $-1.393482^{* *}$ & $-1.242795^{* *}$ \\
\end{tabular}

${ }^{*} p<.05 * * 0<.01{ }^{* * *} p<.001$. Standard errors within parentheses

Source: developed by the authors.

At the next stage, in order to build a model of the dependence of indicators of innovative development of the country on the level of its shadow economy, using the Dickie-Fuller test to identify additional lags.

According to the results, most indicators are stationary. The calculated value is more than the critical value at $1 \%, 5 \%$, and $10 \%$ levels of significance. For example, the value of the ADF test statistic for CIAI for Belgium is more than the critical value $(-2.66)$ and indicates the stationarity of the data analyzed. The results of the Philips Perron Test Statistics allow us to accept the unit root null hypothesis for stationary of majority indicators at the $10 \%$ level of significance. 
I., Tiutiunyk, A., Zolkover, V., Maslov, N., Vynnychenko, M., Samedova, Y., Beshley, O. Kovalenko. Indices of innovation activity as components of macroeconomic stability assessment: how does the shadowing of investment flows affect?

For data series with the rejected the null hypothesis about the presence of a single root in the time series, the first differences of the data series for stationarity were checked. The absolute value of the calculated value of t-statistics in the first differences exceeds the critical values for the significance level of $1 \%, 5 \%$, and $10 \%$. It allows us to reject the null hypothesis about the nonstationarity of the first differences of the data series with a minimum probability of error.

Table 5. The results of testing the data series for stationarity by the Dickey-Fuller and Philips Perron test Statistics

\begin{tabular}{|c|c|c|c|c|c|}
\hline \multirow{2}{*}{ Variables } & \multicolumn{2}{|c|}{ ADF Test Statistics } & \multicolumn{2}{|c|}{ Philips Perron Test Statistics } & \multirow{2}{*}{ Decision } \\
\hline & Test statistic & lag & Test statistic & lag & \\
\hline \multicolumn{6}{|c|}{ BEL } \\
\hline $\mathrm{ClAl}$ & $-4.15207^{\star * *}$ & 1 & $-4.15207^{\star * *}$ & 0 & Stationary \\
\hline SE & -1.22883 & 1 & -1.31788 & 0 & Non-stationary \\
\hline \multicolumn{6}{|c|}{ CZE } \\
\hline $\mathrm{ClAl}$ & $-2.76393^{\star *}$ & 1 & $-3.01192^{* *}$ & 1 & Stationary \\
\hline SE & -2.41319 & 2 & -1.58543 & 0 & Non-stationary \\
\hline \multicolumn{6}{|c|}{ DEU } \\
\hline $\mathrm{ClAl}$ & $-3.79763^{\star *}$ & 1 & $-3.79763^{* *}$ & 1 & Stationary \\
\hline SE & $-2.92572^{\star *}$ & 0 & $-2.92572^{* *}$ & 0 & Stationary \\
\hline \multicolumn{6}{|c|}{ DNK } \\
\hline $\mathrm{ClAl}$ & -0.4656 & 0 & 0.339073 & 1 & Non-stationary \\
\hline SE & $-2.98225^{\star \star}$ & 0 & $-3.13773^{* * *}$ & 0 & Stationary \\
\hline \multicolumn{6}{|c|}{ ESP } \\
\hline $\mathrm{ClAl}$ & $-5.72299^{* * *}$ & 1 & $-4.52449^{* *}$ & 1 & Stationary \\
\hline SE & $-2.12297^{\star *}$ & 1 & $-2.12297^{* *}$ & 1 & Stationary \\
\hline \multicolumn{6}{|c|}{ FRA } \\
\hline $\mathrm{ClAl}$ & 0.58045 & 1 & 0.58045 & 0 & Non \\
\hline SE & $-3.79763^{\star *}$ & 2 & $-3.18542^{* *}$ & 1 & Non \\
\hline \multicolumn{6}{|c|}{ GBR } \\
\hline $\mathrm{ClAl}$ & $-5.53033^{* * *}$ & 1 & $-2.96754^{*}$ & 2 & \\
\hline SE & $-3.11537^{\star \star}$ & 0 & -2.3841 & 2 & Statıonary \\
\hline \multicolumn{6}{|c|}{ HRV } \\
\hline $\mathrm{ClAl}$ & $-2.18225^{\star *}$ & 1 & $-2.82913^{\star *}$ & 2 & Stationary \\
\hline SE & -1.63267 & 2 & -1.43708 & 1 & Non-stationary \\
\hline \multicolumn{6}{|c|}{ EST } \\
\hline ClAI & -1.33998 & 0 & -1.33998 & 2 & Non \\
\hline SE & -0.74594 & 1 & -0.74594 & 1 & Non \\
\hline \multicolumn{6}{|c|}{ AUT } \\
\hline ClAI & $-3.55116^{\star *}$ & 1 & $-3.55116^{* *}$ & 1 & Stationary \\
\hline SE & $-3.47089^{* *}$ & 0 & $-3.47089^{* *}$ & 1 & Stationary \\
\hline \multicolumn{6}{|c|}{${ }^{*} p<.05{ }^{* *} p<.01 * * * p<.001$. Standard errors within parentheses } \\
\hline
\end{tabular}

Source: developed by the authors. 
I., Tiutiunyk, A., Zolkover, V., Maslov, N., Vynnychenko, M., Samedova, Y., Beshley, O. Kovalenko. Indices of innovation activity as components of macroeconomic stability assessment: how does the shadowing of investment flows affect?

Table 6 shows the results of calculating the optimal lag length from the maximum possible selected by the Akaike criteria, the Hannan-Quinn Information Criterion and the Schwartz Information Criterion.

Table 6. The results of the calculation of the length of the lag (fragment)

\begin{tabular}{|c|c|c|c|c|c|c|}
\hline Country & Lag & LR & FPE & AIC & HQIC & SBIC \\
\hline \multirow{14}{*}{ BEL } & \multicolumn{6}{|c|}{$\mathrm{ClAl}$} \\
\hline & 0 & NA & 18.61166 & 5.591037 & 5.388641 & 5.51562 \\
\hline & 1 & 2.31021 & 26.08154 & 6.551595 & 6.789472 & 7.119967 \\
\hline & 2 & 4.220343 & 9.709415 & 5.065806 & 4.557065 & 4.938011 \\
\hline & 3 & 5.666294 & $9.844871^{*}$ & $4.467596^{*}$ & $3.671272^{*}$ & $4.072544^{*}$ \\
\hline & 4 & $315.9395^{*}$ & & -57.7132 & -60.1524 & -58.8209 \\
\hline & 5 & -2.3256 & & -54.7128 & -57.3622 & -52.6707 \\
\hline & \multicolumn{6}{|c|}{ SE } \\
\hline & 0 & NA & 0.29776 & 1.59184 & 1.39167 & 1.51725 \\
\hline & 1 & 3.56776 & 0.22380 & 1.28295 & 0.87800 & 1.13206 \\
\hline & 2 & 16.75243 & 0.00985 & -1.75067 & -2.33282 & -1.96758 \\
\hline & 3 & 11.38601 & $0.00487^{*}$ & $-4.14590^{*}$ & $-5.19665^{\star}$ & $-4.53740^{*}$ \\
\hline & 4 & $246.56544^{*}$ & & -51.78964 & -52.68208 & -52.12211 \\
\hline & 5 & -1.37027 & & -32.36061 & -32.92297 & -32.57011 \\
\hline \multirow{14}{*}{ DEU } & \multicolumn{6}{|c|}{$\mathrm{CIAI}$} \\
\hline & 0 & NA & 0.01364 & -1.37852 & -1.58100 & -1.45396 \\
\hline & 1 & 4.71661 & 0.00787 & -1.92823 & -2.33021 & -2.07800 \\
\hline & 2 & 2.44136 & 0.01010 & -2.28091 & -2.98062 & -2.54161 \\
\hline & 3 & 8.91811 & $0.00705^{*}$ & -3.97109 & -5.08272 & -4.38527 \\
\hline & 4 & $424.10280^{*}$ & & $-88.08748^{*}$ & $-89.40192^{*}$ & $885^{-}$ \\
\hline & 5 & 1.25624 & & -85.31280 & -86.58583 & $\begin{array}{l}88.57717^{*} \\
-85.78706\end{array}$ \\
\hline & \multicolumn{6}{|c|}{ SE } \\
\hline & 0 & NA & 21.67890 & 6.51245 & 6.27670 & 6.42461 \\
\hline & 1 & 2.30414 & 26.01303 & 7.29702 & 6.77164 & 7.10126 \\
\hline & 2 & 4.04242 & 13.72828 & 4.94652 & 4.36494 & 4.72983 \\
\hline & 3 & 5.51805 & $9.53691^{*}$ & 4.25734 & 3.47541 & 3.96600 \\
\hline & 4 & $315.92957^{*}$ & & $-58.44621^{*}$ & $-59.44678^{*}$ & $5801002 *$ \\
\hline & 5 & 1.12145 & & -13.74708 & -13.98242 & $\begin{array}{l}58.81902^{*} \\
-13.83477\end{array}$ \\
\hline \multirow{8}{*}{ DNK } & \multicolumn{6}{|c|}{ CIAI } \\
\hline & & & & & 5.34957 & \\
\hline & 0 & NA & 18.47671 & 5.55050 & 5.21578 & 5.47563 \\
\hline & 1 & 1.77474 & 20.03626 & 5.62045 & 5.31280 & 5.46967 \\
\hline & 2 & 4.92024 & 16.70940 & 6.02066 & $4.22103^{*}$ & 5.75692 \\
\hline & 3 & 6.70191 & $11.58298^{*}$ & $5.17072^{*}$ & - & $4.81687^{*}$ \\
\hline & 4 & $448.505^{*}$ & & -82.97234 & 84.39279 & -83.50160 \\
\hline & 5 & 0 & & -75.53239 & $\begin{array}{c}- \\
76.82485\end{array}$ & -76.01419 \\
\hline
\end{tabular}


I., Tiutiunyk, A., Zolkover, V., Maslov, N., Vynnychenko, M., Samedova, Y., Beshley, O. Kovalenko. Indices of innovation activity as components of macroeconomic stability assessment: how does the shadowing of investment flows affect?

\begin{tabular}{cccccc} 
& \multicolumn{3}{c}{ Countinued Table 6 } \\
\hline & \multicolumn{3}{c}{ SE } \\
\hline 0 & NA & 0.61061 & 3.26438 & 2.85388 & 3.11142 \\
1 & 6.03062 & 0.37829 & 2.16858 & 1.48408 & 1.91353 \\
2 & 28.01363 & 0.01647 & $-2.92749^{*}$ & $-3.90097^{*}$ & $-3.29020^{*}$ \\
3 & 12.41193 & $0.00531^{*}$ & -4.51946 & -5.66489 & -4.94624 \\
4 & $366.54672^{*}$ & & -76.99101 & -78.31772 & -77.48527 \\
5 & -3.15534 & & -74.51686 & -75.81180 & -74.99928
\end{tabular}

Source: developed by the authors.

Calculations allow us to conclude that the optimal lag length for Belgium and Denmark is 3 years, for Germany - 4 years. For the rest of the analyzed countries, the length of the lag ranges from 3 (Czech Republic, Estonia, Austria, Croatia) to 4 (Spain, France, United Kingdom) years.

The next stage of calculations is to test the hypothesis of cointegration of data series. To do this, we calculate the Johansen cointegration test, which is based on assumptions about the linear deterministic trend and the delay interval in the first differences from 3 to 4 . The results of the calculations are shown in table 7.

Table 7. The results of the calculation of the Johansen test (fragment)

\begin{tabular}{ccccccc}
\hline Lag & Coef. & Std. Err. & $\mathbf{z}$ & $\mathbf{P}>|\mathbf{z}|$ & [95\% Conf. Interval] \\
\hline \multicolumn{7}{c}{ BEL } \\
\hline 1 & $-0,07396$ & 0,016733 & $-5,15018$ & 0 & $-0,10675$ & $-0,04116$ \\
2 & $-0,10751$ & 0,018318 & $-6,83972$ & 0 & $-0,14341$ & $-0,0716$ \\
3 & $-0,09724$ & 0,01526 & $-7,42232$ & 0 & $-0,12715$ & $-0,06733$ \\
4 & $-0,08115$ & 0,019984 & $-4,72802$ & 0 & $-0,13875$ & $-0,03891$ \\
& & & CZE & & & \\
1 & $-0,07968$ & 0,018028 & $-5,54887$ & 0 & $-0,11502$ & $-0,04435$ \\
2 & $-0,11583$ & 0,019736 & $-7,3692$ & 0 & $-0,15451$ & $-0,07715$ \\
3 & $-0,10477$ & 0,016441 & $-7,9969$ & 0 & $-0,13699$ & $-0,07255$ \\
4 & $-0,08744$ & 0,021531 & $-5,09402$ & 0 & $-0,14949$ & $-0,04192$ \\
& & & DEU & & & \\
1 & $-0,06255$ & 0,014151 & $-4,35547$ & 0 & $-0,09028$ & $-0,03481$ \\
2 & $-0,09092$ & 0,015491 & $-5,7843$ & 0 & $-0,12128$ & $-0,06055$ \\
3 & $-0,08224$ & 0,012905 & $-6,277$ & 0 & $-0,10753$ & $-0,05694$ \\
4 & $-0,06863$ & 0,016901 & $-3,99845$ & 0 & $-0,11734$ & $-0,03291$ \\
& & & DNK & & & \\
1 & $-0,12602$ & 0,028511 & $-8,77547$ & 0,100 & $-0,1819$ & $-0,07014$ \\
2 & $-0,18318$ & 0,031212 & $-11,6543$ & 0,185 & $-0,24435$ & $-0,12201$ \\
3 & $-0,16569$ & 0,026001 & $-12,647$ & 0,053 & $-0,21665$ & $-0,11473$ \\
4 & $-0,13828$ & 0,034052 & $-8,05614$ & 0,053 & $-0,23642$ & $-0,0663$ \\
\hline
\end{tabular}


I., Tiutiunyk, A., Zolkover, V., Maslov, N., Vynnychenko, M., Samedova, Y., Beshley, O. Kovalenko. Indices of innovation activity as components of macroeconomic stability assessment: how does the shadowing of investment flows affect?

Countinued Table 7

\begin{tabular}{ccccccc}
\hline \multicolumn{7}{c}{ ESP } \\
\hline 1 & $-0,09829$ & 0,022238 & $-6,84455$ & 0,046 & $-0,14187$ & $-0,0547$ \\
2 & $-0,14287$ & 0,024344 & $-9,08993$ & 0,183 & $-0,19059$ & $-0,09516$ \\
3 & $-0,12923$ & 0,02028 & $-9,8642$ & 0,086 & $-0,16898$ & $-0,08949$ \\
4 & $-0,09829$ & 0,022238 & $-6,84455$ & 0,182 & $-0,14187$ & $-0,0547$ \\
\hline
\end{tabular}

Source: developed by the authors.

The results of the calculation of the Johansen cointegration test indicate a stable relationship of longterm equilibrium and allow us to conclude that there is a unilateral impact of the shadow economy on the Complex Innovative Activity Index in all analyzed European countries.

Table 8 shows the results of the calculation of causal links between shadow investment flows and innovative development of European countries indicate the presence of a unilateral impact of shadow transactions with time lags in 1 (Belgium, Denmark, Croatia, Estonia), 2 (Czech Republic, Austria, Spain, Germany) and 3 (France, United Kingdom) years.

Table 8. Results of calculation causal link with the test Granger

\begin{tabular}{cccccc}
\hline Country & Equation & $\mathbf{F}$ & df & df_r & Prob $>$ F \\
\hline \multirow{2}{*}{ BEL } & CIAI $\rightarrow$ SE & 8,9127 & 1 & 6 & 0,0438 \\
& SE $\rightarrow$ CIAI & 0,8608 & 2 & 3 & 0,2738 \\
CZE & CIAl $\rightarrow$ SE & 16,7158 & 1 & 6 & 0,0113 \\
& SE $\rightarrow$ CIAI & 4,7249 & 2 & 3 & 0,2193 \\
DEU & CIAl $\rightarrow$ SE & 0,8217 & 1 & 6 & 0,2159 \\
& SE $\rightarrow$ CIAI & 2,1319 & 2 & 3 & 0,4979 \\
DNK & CIAl $\rightarrow$ SE & 1,7567 & 1 & 6 & 0,2137 \\
& SE $\rightarrow$ CIAI & 1,1239 & 2 & 3 & 0,4004 \\
ESP & CIAl $\rightarrow$ SE & 2,0412 & 2 & 3 & 0,2527 \\
& SE $\rightarrow$ CIAI & 1,4044 & 1 & 6 & 0,2585 \\
FRA & CIAl $\rightarrow$ SE & 7,0492 & 1 & 6 & 0,0332 \\
& SE $\rightarrow$ CIAI & 3,7780 & 2 & 3 & 0,1376 \\
GBR & CIAl $\rightarrow$ SE & 11,9996 & 1 & 6 & 0,0134 \\
& SE $\rightarrow$ CIAI & 5,1140 & 2 & 3 & 0,0347 \\
HRV & CIAI $\rightarrow$ SE & 4,1003 & 1 & 6 & 2,2448 \\
& SE $\rightarrow$ CIAI & 9,5914 & 2 & 3 & 0,1240 \\
EST & CIAI $\rightarrow$ SE & 2,7111 & 1 & 6 & 0,2560 \\
& SE $\rightarrow$ CIAI & 2,1929 & 2 & 3 & 0,3250 \\
AUT & CIAl $\rightarrow$ SE & 1,2233 & 1 & 6 & 0,1395 \\
& SE $\rightarrow$ CIAI & 1,0080 & 2 & 3 & 0,1226 \\
\hline
\end{tabular}

Source: developed by the authors.

Conclusions. The analysis concludes that there is a link between the level of the shadow economy and the country's innovative development. The presence of shadow investment flows leads to a decrease in the country's investment potential, the ability to finance research, technological renewal of production and more. Often it is the high level of the shadow economy that is a deterrent to foreign partners investing in the real sector of the economy. 
I., Tiutiunyk, A., Zolkover, V., Maslov, N., Vynnychenko, M., Samedova, Y., Beshley, O. Kovalenko. Indices of innovation activity as components of macroeconomic stability assessment: how does the shadowing of investment flows affect?

The established interdependencies should serve as a basis for the development and implementation of measures aimed at increasing the innovative activity of economic entities, increasing the innovation potential of the country, and so on.

Author Contributions: N. V., V. M. M.S. - research works of domestic and foreign scientists devoted to the outline of problems associated with the growth of macroeconomic stability are investigated; $Y$. B., O. K. - a grouping of indicators of innovative development of the country; I. T., A. Z., M.S. - the methodical approach to the estimation of the Complex Innovative Activity Indices are proposed, the influence of shadow investment flows on the level of innovation activity of the country is analyzed.

Funding: The paper was executed in the framework of scientific research work «Quadrocentric recrusive model of Ukrainian unshadow economy to increase its macroeconomic stability» (funding National Research Foundation, Application ID: 2020.02/0238)

\section{References}

Bakari, I. H., Idi, A., \& Ibrahim, Y. (2018). Innovation Determinants of Financial Inclusion in Top Ten African Countries: a System GMM Approach. Marketing and Management of Innovations, 4, 98-106. [Google Scholar]

Bara, A., \& Calvin, M. (2016). Financial innovation and economic growth: Evidence from Zimbabwe. Investment Management and Financial Innovations, 13, 65-75. [Google Scholar] [CrossRef]

Bara, A., Mugano, G., \& Le Roux, P. (2016). Financial innovation and economic growth in the SADC. African Journal of Science, Technology, Innovation and Development, 8(5-6), 483-495. [Google Scholar] [CrossRef]

Beck, T., Chen, T., Lin, C., \& Song, F. M. (2012). Financial Innovation: The Bright and the Dark Sides. Hong Kong Institute for Monetary Research Working Papers, 52012. Retrieved from [Link]

Bilan, Y., Vasylieva, T., Lyeonov, S., \& Tiutiunyk, I. (2019). Shadow Economy and its Impact on Demand at the Investment Market of the Country. Entrepreneurial Business and Economics Review, 7(2), 27-43. [Google Scholar] [CrossRef]

Błach, J. (2011). Financial innovations and their role in the modern financial system-identification and systematization of the problem. e-Finanse: Financial Internet Quarterly, 7(3), 13-26. [Google Scholar] []

Bloomberg Innovation Index. (2020). Retrieved from [Link]

Bobenic, H. A., Bruothová, M., Kubíková, Z., \& Rucinský, R. (2018). Determinants of foreign direct investment inflows: A case of the Visegrad countries. Journal of International Studies, 11(2). [Google Scholar] [CrossRef]

Chou, Y., \& Chin, M. (2011). Financial innovations and endogenous growth. Journal of Economics and Management, 25(2), 25-40. [Google Scholar] []

Cisco Global Digital Readiness Index 2019. (2019). Retrieved from [Link]

European Commission. (2020). European Innovation Scoreboard 2020. Retrieved from [Link]

Formankova, S., Trenz, O., Faldik, O., Kolomaznik, J., \& Vanek, P. (2018). The future of investing-sustainable and responsible investing, Marketing and Management of Innovations, 2, 94-102. [Google Scholar]

Global Competitiveness Report 2020. (2020). Retrieved from [Link]

Illicit Financial Flows Reports (IFFR). (2018). Retrieved from [Link]

Kapidani, M., \& Luci, E. (2019). The Effects on innovation from financial sector development: evidence from developing countries. Journal of Competitiveness, 11(2), 84. [Google Scholar] [CrossRef]

Kendiukhov, I., \& Tvaronaviciene, M. (2017). Managing innovations in sustainable economic growth, Marketing and Management of Innovations, 3, 33-42. [Google Scholar]

Kozubikova, L., \& Kotaskova, A. (2019). The impact of technological factors on the quality of the business environment. Transformations in Business \& Economics, 18(46), 95-109. Retrieved from [Link]

Levchenko, V., Kobzieva, T., Boiko, A., \& Shlapko, T. (2018). Innovations in Assessing the Efficiency of the Instruments for the National Economy De-Shadowing: The State Management Aspect. Marketing and Management of Innovations, 4, 361-371. [Google Scholar] [CrossRef]

Loukil, K. (2016). Foreign direct investment and technological innovation in developing countries. Oradea Journal of Business and Economics, 1(2), 31-40. [Google Scholar] 
l., Tiutiunyk, A., Zolkover, V., Maslov, N., Vynnychenko, M., Samedova, Y., Beshley, O. Kovalenko. Indices of innovation activity as components of macroeconomic stability assessment: how does the shadowing of investment flows affect?

Lovell, C. K. (1995). Measuring the macroeconomic performance of the Taiwanese economy. International Journal of Production Economics, 39(1-2), 165-178. [Google Scholar] [CrossRef]

Muhammad, R., Yong, T., \& Muhammad, I. (2020). Financial innovation and economic growth: Empirical evidence from China, India and Pakistan. International Journal of Financial Economy, 7, 1-24. Retrieved from [Link]

Schneider, F. (2015). Size and Development of the Shadow Economy of 31 European and 5 other OECD countries from 2003 to 2015: Different Developments. [Google Scholar]

Sekhar, S., \& Gudimetla, V. (2013). Theorems and theories of financial innovation: models and mechanism perspective. Financial and Quantitative Analysis, FQA, 1(2), 26-29. [Google Scholar]

Subramanian, A., \& Satyanath, S. (2004). What determines long-run macroeconomic stability? Democratic institutions. [Google Scholar]

The Global Innovation Index 2018: Energizing the World with Innovation. (2018). Cornell University, INSEAD, and WIPO: Ithaca Fontainebleau, and Geneva. United Nations Office on Drugs and Crime. Retrieved from [Link]

The Global Innovation Index 2019: Creating Healthy Lives-The Future of Medical Innovation (2019). Cornell University, INSEAD, and WIPO: Ithaca, Fontainebleau, and Geneva. Retrieved from [Link]

Tiutiunyk, I., Kobushko, I., Ivaniy, O., \& Flaumer, A. (2019). Innovations in the Management of Tax Gaps in the Economy: Foreign Economic Component. Marketing and Management of Innovations, 3, 112-125. [Google Scholar] [CrossRef]

Tiutiunyk, I., Vasylieva, T., Bilan, Y., \& Kovalenko, E. (2020). The Impact of Industry 4.0 On the Level of Shadow Employment. The Impact of Industry 4.0 On Job Creation 2019: Proceedings of scientific papers from the international scientific conference. Slovak Republic: Publishing House Alexander Dubcek University in Trencín, 405-413.

United Nations Office on Drugs and Crime. (2018). Retrieved from [Link

Véganzonès-Varoudakis, M. A. (2001). Infrastructures, investissement et croissance: nouvelles évidences empiriques. Revue d'économie du développement, 9(4), 31-46. [Google Scholar]

World Data Bank (2020) Retrieved from [Link]

Zarutska, O., Pavlova, T., Sinyuk, A., Khmarskiy, V., Pawliszczy, D., \& Kesy, M. (2020). The Innovative Approaches to Estimating Business Models of Modern Banks. Marketing and Management of Innovations, 2, 26-43. [Google Scholar] [CrossRef]

Інна Тютюник, д.е.н., доцент, Сумський державний університет, Україна

Андрій Золковер, к.е.н., доцент, Київський національний університет технологій та дизайну, Україна

Владислав Маслов, Університет банківської справи, Україна;

Наталія Винниченко, д.е.н., доцент, Сумський державний університет, Україна;

Самедова Мехрібан Тофік гизи, Ph.D., дочент, Азербайджанський державний економічний університет, Азербайджан

Євгенія Бешлєу, приватний підприємець, Канада

Олена Коваленко, приватний підприємець, Ірландія

Індекси інноваційної діяльності як складові макроекономічної стабільності: дослідження впливу тіньових інвестиційних потоків

Стаття зосереджена на дослідженні причинно-наслідкових зв'язків між рівнями інноваційного розвитку та тінізаціі економіки на прикладі 10 європейських країн. На основі аналізу існуючих підходів до визначення рівня інноваційно активності в країні пропонується лінійна модель оцінки комплексного індексу інноваційної діяльності. Основною гіпотезою статті було припущення, що підвищення рівня тінізації економіки супроводжується зниженням інноваційного розвитку країни, погіршенням доступу до фінансових ресурсів тощо. Метою статті є аналіз співвідношення між рівнем тіньової економіки та показниками інноваційного розвитку країни як складових її макроекономічної стабільності за допомогою аналізу рядів даних з 2007 по 2018 рр. На відміну від попередніх досліджень, дане дослідження обгрунтовуе гіпотезу, про те, що рівень інноваційного розвитку країни залежить від обсягу тіньового сектору економіки. Результати підтверджують взаємозв'язок між ффакторною та результуючими показниками для всіх аналізованих країн. Для підтвердження гіпотези про негативний вплив тіньової економіки на рівень інноваційної діяльності країни була побудова лінійна модель оцінювання Індексу комплексного інноваційного розвитку країни як інтегрального показника 8 міжнародних індексів (Індекс глобальної конкурентоспроможності, Цифрова оцінка готовності, Цифрова економіка та Індекс суспільства, Економічний індекс знань, Європейський індекс інновацій, Індекс інновацій Bloomberg, Міжнародний індекс інновацій, Глобальний індекс інновацій), що характеризує рівень інноваційного розвитку країни. На другому етапі здійснено: тестування рядів даних на стаціонарність за допомогою статистичного тесту Дікі-Фуллера та Філіпса Перрона, розрахунок оптимальної довжини лага, обраної за критерієм Акакайке, інформаційним критерієм ХаннанаКвінна та інформаційним критерієм Шварца, перевірка коінтегрованості рядів даних за допомогою тесту Йогансена. Емпіричні розрахунки довели високий вплив тіньової економіки на інноваційний розвиток країни. Усі показники є 
l., Tiutiunyk, A., Zolkover, V., Maslov, N., Vynnychenko, M., Samedova, Y., Beshley, O. Kovalenko. Indices of innovation activity as components of macroeconomic stability assessment: how does the shadowing of investment flows affect?

статистично значущими на рівні $1 \%$ та 5\% та 10\% відповідно. Обгрунтовано, що держава повинна враховувати встановлені взаємозалежності як основу для розробки та реалізації заходів, спрямованих на підвищення інноваційної активності суб'єктів господарювання, збільшення інноваційного потенціалу країни тощо.

Ключові слова: інноваційна діяльність, інвестиційні потоки, макроекономічна стабільність, тіньова економіка, індекси

Manuscript received: 01.12.2020

(c) The author(s) 2020. This article is published with open access at Sumy State University 